\title{
The microbiological quality of various foods dried by applying different drying methods: a review
}

\author{
Duygu Alp ${ }^{1}\left[\right.$. Özcan Bulantekin ${ }^{1}$
}

Received: 25 January 2021 / Revised: 18 March 2021 / Accepted: 20 March 2021 / Published online: 2 April 2021

(c) The Author(s), under exclusive licence to Springer-Verlag GmbH Germany, part of Springer Nature 2021

\begin{abstract}
With the drying process, the water activity and moisture content of the foods are reduced, so the growth of microorganisms in the foods is largely prevented/postponed. But low-aw foods should not be considered sterile they can be contaminated by fungi and other contaminants during the drying process under unhygienic conditions. If drying is not done to a sufficient degree of moisture during food processing and storage, where dried foods are processed, sometimes the minimum value is reached for the growth of microorganisms. In dry foods, some pathogens, yeast and molds can continue to grow during storage, transport and transportation until the sale and they causing spoilage. They can even cause health problems if enough pathogen or spore cells remain viable. Considering this situation today, it is attempted to obtain high-quality dried foods with good microbiologically and chemically properties. For this purpose, various drying methods have been developed. Most studies suggest that when foods are pre-treated with the ascorbic acid or sodium metabisulfite or applied with various combined methods such as UV irradiation, supercritical carbon dioxide $\left(\mathrm{SCO}_{2}\right)$, low-pressure superheated steam drying (LPSSD), and infrared (IR) drying, they can be effective on inactivation of microorganisms. We have reviewed in this study how these methods made dried products efficient of microbial inactivation and microbiologically safe.
\end{abstract}

Keywords Food safety $\cdot$ Microbial inactivation - Bacterial survivor · Drying methods · Dried fruits and vegetables . Emerging technologies in food processing

\section{Introduction}

Dried vegetables in the eighteenth century was one of the first-recorded industrially dried foods. With the wars that emerged over time, the drying industry has improved. In the Crimean War between 1854 and 1856, it was reported that they met the nutritional requirements with dried vegetables sent from the countries of the British army. During World War I, 4500 tons of dehydrated food (green beans, cabbage, carrots, potatoes, spinach, corn, radish, and soup mixtures) were sent from Europe to the battlefields by ships from the United States [1]. In the USA, fruit drying has shown a significant leap in the late 1800s and early 1900s, and natural drying systems have been replaced by artificial

Duygu Alp

duygualp1@gmail.com

Özcan Bulantekin

obulantekin@gmail.com

1 Department of Food Engineering, Faculty of Engineering, Süleyman Demirel University, Isparta, Turkey drying systems. In the periods before World War II, roller and spray dryers were used and the most dried products in these systems were milk and eggs. Military use has played an essential role in the recognition and popularization of drying. Drying was carried out naturally only with the sun in the old dates. However, it is no longer preferred because of the hygienic factors such as sun rays being effective only in certain periods of the year, needing large areas and long time, insecticide, and pollination. Nowadays, with the advancement of technology, drying processes can be carried out with many different methods [2].

Drying methods most commonly used in the food industry, sun drying, conventional dryers (tray, tunnel, drum), spray dryers, fluidized bed dryers, freeze, vacuum or microwave drying [3]. In addition to these methods, microwavevacuum, microwave-freeze, puffing, instant controlled pressure drop (DIC), superheated steam (SSD), infrared radiation (IR), radiofrequency, electrohydrodynamic (EHD), ultrasonic, supercritical $\mathrm{CO}_{2}$ drying and combinations of these methods are some novel technologies used for good quality dried food products $[4,5]$. 
Fruits and vegetables have become rich in proteins, carbohydrates and many vitamins, minerals also they are sources of fiber for humans. Diets are balanced and beneficial to health when they are rich in fruits and vegetables. They can also prevent some important vitamin (such as $\mathrm{C}$ and $\mathrm{A}$ ) deficiencies and reduce the risk of various diseases [6-8]. With increases of the awareness in the consumer, consumption of fresh and raw foods and increasing demand for these products continue every year [9]. Despite all these good functions for health, these raw foods may be contaminated with molds, fungi, or various pathogen microorganisms such as Escherichia coli O157:H7, Listeria monocytogenes, Staphylococcus aureus, and Salmonella spp. [7, 10]. This contamination usually results from contact with soil, dust, and wastewater during harvest and post-harvest periods [6, 7]. These microorganisms may cause various serious diseases such as diarrhea, vomiting, cramps, even death. Generally, microflora in vegetables is associated with Gram-negative bacteria while the fruit flora generally consists of yeasts and molds [11]. Due to this microorganism load, there are some disadvantages of vegetable and fruit consumption without any treatment. Among them, short shelf life, they should be more easily degraded due to microbial load, and are likely to cause food poisoning or foodborne infection [7, 8]. Therefore, nowadays, various drying methods are used to preserve the properties of food and without high heat treatment. The drying process prevents the growth of these microorganisms due to contamination or naturally found in fruits and vegetables and cause food deterioration, and also contributes to stopping an enzymatic or non-enzymatic browning reaction $[5,12]$. Drying of fruits and vegetables helps prolong shelf life with reduced microorganism viability, also decrease packaging requirements and transport weight [13]. Generally, the minimum aw at which microorganisms can grow is 0.60 , but these numbers are variable, for example, halophilic bacteria can grow at 0.75 , but these numbers for most bacteria are about 0.87 [14]. Therefore. low water activity (aw) of dried fruits and vegetables is generally at 0.70 [15]. Despite these advantages of low-aw foods, various microorganisms, including food-borne pathogens, can survive these processes [14]. Low-aw foods are not sterile and can be contaminated by fungi and other contaminants during the drying process under unhygienic conditions, even, these microorganisms may be present in the primary product. Also, if drying is not done to a sufficient degree of moisture during food processing and storage, where dried foods are processed, sometimes the minimum value is reached for the growth of microorganisms. As a result of this situation, some pathogens such as Staphylococcus aureus can remain in dry foods longer and continue to grow during storage, transport and transportation until the sale and they causing spoilage $[14,16]$.

There may be various molds that are already present in dried vegetables or that come with contamination during the drying process, they can cause foodborne disease, in particular, they can produce various toxins such as aflatoxin in dried figs. Mycotoxins can affect consumer health and food quality, and as a result of these conditions, the commercial value of the products may be lost $[16,17]$.

In this study, we reviewed that the pre-treatments and applications applied to reduce the microbial loads of dried products, prolong their shelf life and improve their quality. Although aw and moisture content are low compared to other food groups, it should be known that there may be development of microorganism when dried foods suffer from moisture when they are stored under unhygienic drying conditions, contamination and/or storage conditions. To shed light on the fruit and vegetable drying industry and highlight its importance for public health, we conducted a review study showing how effective the various methods are in terms of microorganism inactivation and food quality.

\section{Results and discussion}

\section{Some applications and pretreatments for microorganism inactivation}

Pretreatment means that the humidity of the agricultural products will be removed faster before they dry; it might be done for preservation/enhancement of colors, flavors, and nutritional values. It is the whole of physical and chemical processes that are carried out to ensure hygienes by preventing possible microbial activities on them and to obtain shape and size characteristics in accordance with the standards [18].

Most studies have shown that pretreating with an acidic solution (ascorbic, citric acid, etc.) or sodium metabisulfite dip also enhances the destruction of potentially pathogenic bacteria during drying and storage, including $E$. coli O157:H7, Salmonella spp. and Listeria monocytogenes, and enhance the safety of dried fruits $[19,20]$. However, sulfur and sulfite compounds may lead to asthmatic reactions in some people.

There are some studies of inactivation of microorganisms by dipping or soaking a product in ascorbic acid [21, 22], citric acid [22, 23], lactic acid [24], and acetic acid $[25,26]$. These solutions can help reduce the number of normal flora and pathogenic microorganisms and also reduce the enzyme activity that causes browning [27]. Additionally, alkaline solution ( $\left.\mathrm{NaOH}, \mathrm{Na}_{2} \mathrm{CO}_{3}, \mathrm{~K}_{2} \mathrm{CO}_{3}\right)$ applied by dipping or spraying, salting, and immersion in $\mathrm{NaCl}$ solution used in drying of fruits and vegetables are of great importance [28-30]. These can be applied alone or in combination with other methods, for example, the application of citric acid + salt in drying tomatoes [31]. Blanching is one of the most widely used methods 
of inactivation of microorganisms. It can be performed in different ways such as dipping in hot water, hot or boiling solutions containing acids and/or salts, or steam for few minutes [32]. Some gases such as ozone and chlorine dioxide are used in dried products to prevent microbial growth [33, 34].

Thanks to the cavitation created by ultrasound, microorganisms have the effect of killing cell walls by breaking them $[35,36]$. While ultrasound alone is not enough to inhibit all microorganisms in the environment, its effect increases when combined with heat and pressure. These applications are thermosonication, monosonication, and monothermosonication [37].

High hydrostatic pressure (HHP) application: it is applied as a non-heat treatment technology that can reduce the number of microorganisms and increase the shelf life by improving microbial reliability in many foods such as fruit jams, fruit juices, guacamole, sauces, oysters and packaged cured ham [38].

Ultraviolet (UV) irradiation is applies for fungal decontamination and degradation of aflatoxin in dried fig fruits and IR heat to the bacterial spores resulted in an excellent killing efficiency especially of highly heat-resistant microbial spores (Bacillus subtilis, Aspergillus niger) [39-41]. The combination of IR heating with UV irradiation markedly accelerated killing efficiency of microorganisms [42]. Irradiation technology is an effective method of sterilization that preserves the nutritional properties of foods and is used to extend the shelf life [43].

Cold plasma treatment (CPT) is a potential alternative nonthermal processing technology for decontamination of foods [44]. Cold plasma is formed by the stimulation of some gases $\left(\mathrm{O}_{2}, \mathrm{He}, \mathrm{Ar}, \mathrm{H}_{2}\right.$, etc. $)$ under vacuum and at room temperature by applying an electric current or electromagnetic radiation. Radiofrequency, microwave, UV, and X-ray can also be used in cold plasma production [45, 46]. The other nonthermal processing technology pulsed electric field (PEF) treatment involves the application of electric field to fluid foods placed between two electrodes in batch or continuous flow system which is used for inactivation of microorganisms, to decrease the activity of enzymes and extend the shelf life of foods without significant loss of flavor, color and nutrients [47-49]. The other applications of electromagnetic fields for nonthermal inactivation of microorganisms are high-voltage arc discharge (HVAD) and pulsed light (PL) [50].

Supercritical carbon dioxide $\left(\mathrm{scCO}_{2}\right)$ is a low-temperature novel drying technique which combines the extraction of water from fruits and the reduction of the microbial load and thus preserves the original properties of the fruits [51, 52]. Table 1 shows the results of microorganism inactivation by the studies using different drying methods.

\section{Effect of drying process on microorganisms and survival mechanisms of microorganisms in low water activity}

Microbial cell viability is more stable in dry state; therefore, dry heat is less effective than moist heat in microbial inactivation [53, 54]. In fact, during the drying process, various changes are observed in the structure of the microorganism. For example, cell wall damage and protein denaturation happens by removal of water $[55,56]$.

Some acids in foods (such as acetic or ascorbic acid) can affect the thermal stability of bacteria, but they at the same time increase the ability of microorganisms to survive during dehydration $[57,58]$. For this reason, such components (sugars, polypeptides, polyalcohols, amino acids) use during the drying of various strains like starter/ pure cultures $[59,60]$. Some foods with such components can also be called low-acid foods. Acid-rich fruits have a low $\mathrm{pH}$, which, when combined with various methods, speeds up the death of the microorganism. Therefore, the survival of microorganisms during drying can be related to the structure of the food [58].

The growth of microorganisms in foods is largely prevented/delayed by drying. However, since dry foods have hygroscopicity and the moisture content is not constant, the relative humidity in the air in the storage is important. When the relative humidity and moisture content balance is disturbed, a suitable moisture environment is created especially for mold growth. After drying, there may be enough pathogens and spore cells to cause the disease, even they can remain viable for months and this can cause health problems $[14,16]$.

Microorganisms (especially some pathogens) can survive low water activity [61]. Therefore, a more efficient process like combined methods is required to inactivate or kill the microorganisms during drying [62]. Various technologies are applied to foods for the inactivation of the microorganisms. Some of these methods are temperature and pressure changes, atmospheric changes by increased carbon dioxide or azote concentrations, and electromagnetic waves [57].

By drying processes, bacteria are confronted with stress environments such as high or low temperature, higher osmolality, and acidic $\mathrm{pH}$. The response of microorganisms to this type of stress environment is in the form of preventing cellular damage rather than repair [63]. Some of these responses are the accumulation of osmoprotectant molecules, biofilm formation, and filamentation [58]. In an environment with low water activity, intracellular and extracellular osmolarity should be balanced to prevent dehydration. To this end, bacteria accumulate various osmoprotectants (such as $\mathrm{KCl}$, glutamate, and trehalose) that help limit cell water loss [61]. When bacteria dried, the strength of the resonance of water molecules is less effective due to the low water amount. 
Table 1 The results of microorganisms inactivation by the studies using different drying methods

\begin{tabular}{|c|c|c|c|c|c|}
\hline Drying method & Microorganisms & Food & Conditions & $\begin{array}{l}\text { Effect/approximate } \\
\text { reduction log }(\mathrm{cfu} / \mathrm{g})\end{array}$ & References \\
\hline Convective air drying & L. monocytogenes & Peach slices & $6 \mathrm{~h}$ at $60^{\circ} \mathrm{C}$ & 5.30 & DiPersio et al. (2004) \\
\hline Convective air drying & E. coli $\mathrm{O} 157: \mathrm{H} 7$ & Apple slices & $6 \mathrm{~h}$ at $62^{\circ} \mathrm{C}$ & 3.50 & Burnham et al. (2001) \\
\hline $\begin{array}{l}\text { Microwave freeze } \\
\text { drying }\end{array}$ & Mesophilic bacteria & Cabbage slices & $6 \mathrm{~h}$ at $100 \mathrm{~Pa} 700 \mathrm{~W}$ & 0.90 & Duan et al. (2007) \\
\hline Freeze drying & Mesophilic bacteria & Cabbage slices & $15 \mathrm{~h}$ at $100 \mathrm{~Pa}$ & Almost no reduction & Duan et al. (2007) \\
\hline Convective air drying & S. anatum & Cabbage slices & $3 \mathrm{~h}$ at $60^{\circ} \mathrm{C}$ & 4.50 & $\begin{array}{l}\text { Chiewchan and Mora- } \\
\text { kotjinda (2009) }\end{array}$ \\
\hline Convective air drying & S. anatum & Cabbage & $2.5 \mathrm{~h}$ at $50-70{ }^{\circ} \mathrm{C}$ & 4.50 & Haware et al. (2009) \\
\hline Convective air drying & S. anatum & Cabbage slices & $4 \mathrm{~h}$ at $70^{\circ} \mathrm{C}$ & 6.30 & $\begin{array}{l}\text { Phungamngoen et al. } \\
\text { (2011) }\end{array}$ \\
\hline Vacuum drying & S. anatum & Cabbage slices & $1.5 \mathrm{~h}$ at $70^{\circ} \mathrm{C} 10 \mathrm{kPa}$ & 3.30 & $\begin{array}{l}\text { Phungamngoen et al. } \\
\text { (2011) }\end{array}$ \\
\hline LPSSD drying & S. anatum & Cabbage slices & $1.75 \mathrm{~h}$ at $70^{\circ} \mathrm{C} 10 \mathrm{kPa}$ & 6.70 & $\begin{array}{l}\text { Phungamngoen et al. } \\
\text { (2011) }\end{array}$ \\
\hline Convective air drying & S. typhimurium & Carrot slices & $6 \mathrm{~h}$ at $60^{\circ} \mathrm{C}$ & $1.65 \mathrm{cfu} / \mathrm{g}$ & DiPersio et al. (2007) \\
\hline $\begin{array}{l}\text { Microwave vacuum } \\
\text { drying }\end{array}$ & $\begin{array}{l}\text { Total aerobic count, } \\
\text { yeasts and molds }\end{array}$ & Carrot slices & $58 \min 15 \mathrm{kPa} 1800 \mathrm{~W}$ & 1.7 and $1.5-2.2$ & $\begin{array}{l}\text { Yaghmaee and Durance, } \\
\text { (2007) }\end{array}$ \\
\hline $\begin{array}{l}\text { Microwave + microwave } \\
\text { vacuum drying }\end{array}$ & $\begin{array}{l}\text { Total aerobic count, } \\
\text { yeasts and molds }\end{array}$ & Carrot slices & $\begin{array}{l}12 \text { then } 46 \min 15 \mathrm{kPa} \\
1800 \mathrm{~W}\end{array}$ & 4.0 and $1.3-3.9$ & $\begin{array}{l}\text { Yaghmaee and Durance, } \\
\text { (2007) }\end{array}$ \\
\hline $\begin{array}{l}\text { Catalytic infrared } \\
\text { drying }\end{array}$ & Mesophilic bacteria & Onion & $40 \mathrm{~min}$ at $80^{\circ} \mathrm{C}$ & 1.7 & Gabel et al. (2006) \\
\hline Conventional drying & E. coli $\mathrm{O} 157: \mathrm{H} 7$ & Tarhana & $36 \mathrm{~h}$ at $55^{\circ} \mathrm{C}$ & 2.0 & Dağlıoğlu et al. (2002) \\
\hline Microwave drying & E. coli $\mathrm{O} 157: \mathrm{H} 7$ & Tarhana & 36 h $1500 \mathrm{~W}$ & 4.0 & Dağlıoğlu et al. (2002) \\
\hline Convective air drying & E. coli $\mathrm{O} 157: \mathrm{H} 7$ & Apple slices & $6 \mathrm{~h}$ at $62.8^{\circ} \mathrm{C}$ & 3.0 & $\begin{array}{l}\text { Derrickson-Tharrington } \\
\text { et al. (2005) }\end{array}$ \\
\hline $\begin{array}{l}\text { Acid treatment }+ \text { con- } \\
\text { vective air drying }+\end{array}$ & E. coli $\mathrm{O} 157: \mathrm{H} 7$ & Apple slices & $6 \mathrm{~h}$ at $62.8^{\circ} \mathrm{C}$ & 6.0 & $\begin{array}{l}\text { Derrickson-Tharrington } \\
\text { et al. (2005) }\end{array}$ \\
\hline $\begin{array}{l}\text { Acid treatment }+ \text { con- } \\
\text { vective air drying }+\end{array}$ & S. typhimurium & Apple slices & $6 \mathrm{~h}$ at $60^{\circ} \mathrm{C}$ & 4.3 and 5.2 & DiPersio et al. (2003) \\
\hline $\begin{array}{l}\text { Supercritical carbon } \\
\text { dioxide }(\mathrm{scCO} 2)\end{array}$ & $\begin{array}{l}\text { Yeasts, molds and } \\
\text { Mesophilic bacteria }\end{array}$ & Herbs & $\begin{array}{l}0-150 \min 10 \mathrm{MPa} \text { at } \\
40-50^{\circ} \mathrm{C}\end{array}$ & 2.0 and 4.0 & Zambon et al. (2018) \\
\hline Ozone gas & $\begin{array}{l}\text { Yeasts, molds and } \\
\text { E.coli Mesophilic } \\
\text { bacteria }\end{array}$ & Figs & 13.8 and $1.7 \mathrm{mg} \mathrm{L}^{-1}$ & Complete inactivation & Zorlugenç et al. (2008) \\
\hline Ozonated water & $\begin{array}{l}\text { Yeasts, molds and } \\
\text { E.coli Mesophilic } \\
\text { bacteria }\end{array}$ & Figs & $7.5,15,30 \mathrm{~min}$ & $0.16-1.57-2.09$ & Zorlugenç et al. (2008) \\
\hline Ozonation & E. coli & Figs & $\begin{array}{l}0.1,0.5,1.0 \mathrm{ppm} \\
36 \mathrm{~min} \text { at } 20^{\circ} \mathrm{C}, 70 \% \\
\text { relative humidity }\end{array}$ & $1.0-2.0-3.5$ & $\begin{array}{l}\text { Akbaş and Özdemir } \\
\text { (2008) }\end{array}$ \\
\hline Ozonation & Bacillus cereus & Figs & $\begin{array}{l}0.1,0.5,1.0 \mathrm{ppm} \\
36 \mathrm{~min} \text { at } 20^{\circ} \mathrm{C}, 70 \% \\
\text { relative humidity }\end{array}$ & $2.0-3.0-3.5$ & $\begin{array}{l}\text { Akbaş and Özdemir } \\
\text { (2008) }\end{array}$ \\
\hline Ozonation & $\begin{array}{l}\text { Bacillus cereus and } \\
\text { spores }\end{array}$ & Figs & $\begin{array}{l}1.0,5.0,7.0 \text { and } 9.0 \mathrm{ppm} \\
36 \mathrm{~min} \text { at } 20{ }^{\circ} \mathrm{C}, 70 \% \\
\text { relative humidity }\end{array}$ & $0.5-1.0-1.5-2.0$ & $\begin{array}{l}\text { Akbaş and Özdemir } \\
\text { (2008) }\end{array}$ \\
\hline
\end{tabular}

Also, this situation helps prevent the denaturation of membrane proteins even at high temperatures [64].

Biofilms are composed of microcolonies that are known to adhere to each other and/or surfaces or interfaces enclosed in a highly hydrated polymeric matrix [65]. Bacteria form biofilms consisting of extracellular polysaccharides, proteins, and nucleic acids to be protective when the stress environment is formed [58].

Another response to stress conditions is structural change that is often seen in bacteria when exposed to stress. This change is reduction in cell size or cell elongation. Low water activity can cause filament formation, but this formation 
does not increase cell number, and causes increased overall biomass [66]. When exposed to refrigeration temperatures, E. coli and Salmonella enterica subsp. enterica serovars Enteritidis and $S$. typhimurium are known to develop filaments [67]. Thanks to these resistance mechanisms, microorganisms can get rid of disinfection and contact the surfaces; therefore, they cause contamination of food. For this reason, different combinations are developed in drying methods.

\section{Are drying processes successful in the inactivation of microorganisms on dried food?}

Drying is a frequently used process to protect food products. This process based on dehydration significantly reduces the water activity of the food, thereby helping to delay the kinetics that affect the deterioration of the food [21, 26]. Some acidic fruits can have a low $\mathrm{pH}$, which can be damaging to microorganisms, and due to their complex structure, there may be serious changes in the survival of microorganisms during the drying of fruits. Unfortunately, fruits and vegetables have many compounds which are increasing the survivability of the microorganisms during dehydration, certain sugars such as sucrose and amino acids can increase the ability of bacteria to survive in the preservation processes $[60,68]$. For this reason, different technologies have been added to the drying processes for the inactivation of microorganisms, and additions have been made to stress factors such as low water activity.

One of these technologies is the pretreatment application before drying. Using different acid solutions is one of them. Burnham [70] reported that they dried the Gala apple in two different ways. Just dehydrating treatment of apple at $62.8^{\circ} \mathrm{C}$ for $6 \mathrm{~h}$ provided approximately a $3.2 \mathrm{log}$ reduction of $E$. coli $\mathrm{O} 157: \mathrm{H} 7$ populations; however, when the slices were pre-dried with $3.4 \%$ ascorbic acid solution, the number of microorganisms was about twice as much logarithmic decline. Derrickson-Tharrington [20] compared convective air drying and various acid pretreated drying processes. In the convective air drying, while the E. coli $\mathrm{O} 157$ : $\mathrm{H} 7$ population decreased by about 3 logarithms, this count was an average of 6 logarithms in acid applications and almost all pathogens were inactivated. Dipersio [19] indicated that pretreatment with metabisulfite or acidic solutions enhanced the inactivation of Salmonella during dehydration and storage. Pathogen load on slices treated with these acids was reduced approximately 4.3 and $5.2 \mathrm{log}$ cfu/g, respectively. Bang [71] investigated how the combination of $\mathrm{ClO}_{2}$ and mild dry heat treatments affect microorganism inactivation. At the end of the study, the results show that this method inactivates total aerobic bacteria, E. coli $\mathrm{O} 157$ : $\mathrm{H} 7$, mold and yeast on radish seeds. Also, the application of 200 to $500 \mathrm{mg} / \mathrm{ml} \mathrm{ClO}_{2}$ for radish seeds reduced the total aerobic bacteria by about 5.1 $\log$. And when samples were treated with 200 and $500 \mathrm{mg} /$ $\mathrm{ml} \mathrm{ClO}_{2}$, air dried, and heated, E. coli $\mathrm{O} 157: \mathrm{H} 7$ was reduced to an undetectable level $(<0.8 \log \mathrm{cfu} / \mathrm{g})$. Results show that this combined process will be useful to enhance the microbiological safety of radish sprouts.

DiPersio [21] determined the effect of drying peach slices with $4.18 \%$ sodium metabisulfite, $3.40 \%$ ascorbic acid, and $0.21 \%$ citric acid solutions on the viability of L. monocytogens. Initially, this microorganism number was $7.9 \mathrm{log} \mathrm{cfu} / \mathrm{g}$. Immersion in the sodium metabisulfite solution reduced populations by $5.43 \log \mathrm{cfu} / \mathrm{g}$, acetic acid $6.15 \mathrm{log} \mathrm{cfu} / \mathrm{g}$, and citric acid $5.25 \mathrm{log}$ cfu/g after $6 \mathrm{~h}$ of dehydration. DiPersio [72] showed that in Nantes carrot slices pre-treatment with acid solution reduced viability in Salmonella spp. Also by Chiewchan and Morakotjinda [26] reported that the same results in white cabbage slices for Salmonella spp. Hawaree et al. [62] determined how hot-air drying temperature $\left(\sim 70{ }^{\circ} \mathrm{C}\right)$ affects Salmonella anatum on the surface of cabbage. They determined that with longer drying time and higher drying temperature the water activity of the vegetable decreased and reduction rate increased. All these results show that convective air drying at low temperatures $\left(\sim 60^{\circ} \mathrm{C}\right)$ alone is not an effective method than combining with various solution pre-treatments.

Bacterial species have different sensitivity to heating and drying processes [54]. Therefore, researchers obtained different viability during thermal drying. Convective air drying process is carried out at $40-80{ }^{\circ} \mathrm{C}$ at atmospheric pressure in various dryers (tray, cabinet, tunnel, conveyor belt dryer). The drying time should be between a few hours and a day, and the temperature of the product to be dried should not be higher than the drying air [68]. Drying under the sun is the best-known method used in reducing the moisture content of agricultural products and preventing deterioration that may occur during storage. Solar radiation is used as an energy source in this natural drying. The material is rotated to continuously affect every point and increase drying efficacy, and one of the known disadvantages is long drying times [68, 72]. Kudjawu et al. [73] reported on the natural microflora of various dried vegetables by sun-drying method, and the results showed that the most common microorganisms in dried vegetables are mold and Bacillus spp. They also isolated lactic acid bacteria and coliforms. These results demonstrate that this microflora may have come from the raw material, the equipment on the processing line and the warehouse and that it is necessary to disinfect fresh vegetables before drying them in sun dryers. Bai et al. [74] have investigated the effectiveness of osmotic dehydration and cold infusion combination in the inactivation of related bacteria using blueberries. At the end of the study, no bacteria strain remained alive except for Enterococcus faecium in the samples dried at $40{ }^{\circ} \mathrm{C}$ by adding sugar. The combined process provided approximately an $6 \log$ reduction of all 
tested bacterial strains. All these results showed that osmotic dehydration is successful for the inactivation of pathogens at $40{ }^{\circ} \mathrm{C}$ or at $23{ }^{\circ} \mathrm{C}$ and followed by air-drying at $100{ }^{\circ} \mathrm{C}$. Considering these results, classical drying methods take a long time and are inadequate in inactivation. Therefore, recently combined methods have been developed and used.

Vacuum drying which reduces the humidity of the food is the removal of moisture from food products takes place under low pressure. Then water vapor is constantly removed from the drying vessel [75]. To take advantage of this feature, Phungamngoen et al. [53] determined and compared the effects of various drying methods (convective air drying, vacuum drying, and low-pressure SSD) on the heat resistance of Salmonella spp. attached on the surface of white cabbage. The results showed that drying methods were highly effective on the inactivation rate of Salmonella spp. Also, they indicated that the inactivation rate was significantly higher for vacuum and low-pressure SSD. When the results were evaluated, they stated that the most effective method for reducing the number of Salmonella spp. is LPSSD. This drying method can be effective in microorganism inactivation as the steam temperature is over $100{ }^{\circ} \mathrm{C}$. Yaghmaee and Durance [76] compared a combination of vacuum microwave drying and atmospheric pressure microwave processing in freshly grated carrots and parsley. In the vacuum microwave process for freshly grated carrots, approximately $1.7 \mathrm{log}$ reduction in total aerobic counts and 1.5 and $2.2 \log$ reduction in yeast and mold population, respectively, for parsley, reduction was 2.5 for total aerobic count and 2.7 for both yeast and mold population. They obtained a higher microbial reduction with the combination process, that is, at only atmospheric pressure. And they have an opinion that these results may be due to reaching a higher temperature at atmospheric pressure than under vacuum.

Microwave technology in drying food can penetrate and heat food without any additional thermal material [16, 77]. There are a lot of studies on the reduction of microorganisms in various foods using microwaves. And these works show that microwave radiation reducing microbial cells in food. Some pathogens like E. coli, S. faecalis, C. perfringens, S. aureus, Salmonella, and Listeria spp. are known to inactivate by microwave heating [78]. One of these studies is by Daglioglu et al. [79]. They compared microwave and conventional drying on the inactivation of some pathogens in tarhana. For this purpose, they inoculated tarhana with $E$. coli $\mathrm{O} 157: \mathrm{H} 7$, S. aureus and E. coli $\mathrm{O} 157: \mathrm{H} 7+$ S. aureus, separately. Microwave drying almost killed all $S$. aureus, they were $102 \mathrm{cfu} / \mathrm{g}$ at the end of the fermentation process and the number of $E$. coli $\mathrm{O} 157: \mathrm{H} 7$ decreased approximately 2 logarithmic at the end of the 3rd day, also at the end of the process, it was observed that they completely lost their vitality. They concluded that microwave drying was more efficient than the conventional method. Guirguis
[80] determined the microbiological and mycotoxin quality of various fruits after being dried and exposed to further microwave treatment. The results showed that most samples were contaminated with aerobic mesophilic bacteria, molds and yeasts count as well as spore-forming bacteria. However process succeeded inactivation of the pathogens, any pathogens were not detected. But microwave treatment was not enough success against mycotoxins. The destruction mechanism of microorganisms by the microwave is not fully understood. But general thought is a thermal effect of microwave radiation however some researchers say the opposite of this thought. Kozempel et al. [81] indicated that microwave stress is more effective than conventional heat for microorganisminactivation.

Similar to microwave energy, infrared is absorbed by foodstuffs and is then converted to heat. Infrared radiation can destroy DNA, RNA, ribosome, cell envelope and proteins of the microorganism by thermal inactivation and is therefore widely used to inactivate bacteria, spores, yeasts and molds in solid foods. Among the factors affecting microbial inactivation are food temperature, depth, moisture content and microorganism type. This method was applied to potatoes, kiwi, apples, onions, and other vegetables [82-84]. Gabel et al. [85] compared catalytic infrared dehydration and air convection heating. Their results showed that in both drying methods at $80^{\circ} \mathrm{C}$, the aerobic plate counts decreased the same and approximately $1.7 \mathrm{log} \mathrm{cfu} / \mathrm{g}$; however, for yeasts and molds, a significant difference was observed between these two drying methods. However, when yeast and mold counts take into account samples dried by the catalytic infrared (CIR) had significantly lower than those by the forced air convection (FAC). In the CIR dryer microorganism's inactivation was greater because it has greater heat fluxes. Supercritical liquids, whose behavioral properties resemble gaseous but are similar to liquids in terms of density, have been used as extraction solvents in the food industry since the early 1980s. Also their diffusivity is better than that of a liquid and has good mass transferability.

Most food process uses supercritical carbon dioxide $\left(\mathrm{scCO}_{2}\right)$ as the solvent because they are accepted Safe (GRAS) When this liquid is applied for $15 \mathrm{~min}$ at $150 \mathrm{bar}$ operating pressure, it shows the same effect with high hydrostatic pressure the same temperature and at 3000 bar, and provides the same microbial reduction $[68,86]$. Calvo and Torres [87] used the high-pressure $\mathrm{CO}_{2}$ for the inactivation of the natural microbiota in paprika and an evaluation of its effects on product quality. For the method to be effective, first on the presence of water, and a higher water content required and pressure should be at relatively low levels (60-100 bar) for the contribute to sporicidal mechanism inactivation. Also to avoid a loss of product quality, temperature should be on average $85-90^{\circ} \mathrm{C}$. When these conditions are met the method could be a useful alternative to 
traditional moist-heat treatments or hydrostatic processes. Zambon et al. [88] indicated that using supercritical carbon dioxide $\left(\mathrm{scCO}_{2}\right)$ as a drying agent is effective in microbial inactivation in herbs. Study results show that after treatment yeasts and molds undetected $(<2 \log \mathrm{cfu} / \mathrm{g})$, and mesophilic bacteria significantly reduced, up to $4 \log \mathrm{cfu} / \mathrm{g}$, but remained above the limit of quantification. In this regard, results show that $\mathrm{scCO}_{2}$ drying was an effective method in microbial inactivation.

Bourdoux et al. [68] inoculated E. coli O157: H7, Salmonella and Listeria monocytogenes in the coriander, and dried by applying supercritical $\mathrm{CO}_{2}$ and freeze-drying, then they compared the results. Sample dried by $\mathrm{scCO}_{2}$ at $35^{\circ} \mathrm{C}$ for $150 \mathrm{~min}$ at $80 \mathrm{bar}$. At the end of the process, the aerobic plate count, yeasts and molds, and the Enterobacteriaceae were reduced by $2.80,5.03$, and $4.61 \mathrm{log} \mathrm{cfu} / \mathrm{g}$, respectively. But the total count of mesophilic aerobic spores was not significantly reduced. The pathogens were reduced by $>5.18$ $\log \mathrm{cfu} / \mathrm{g}$. As for the freeze-drying results is; reductions 1.23, 0.87 , and $0.97 \log \mathrm{cfu} / \mathrm{g}$, respectively. The freeze-drying results are 1.53 for E. coli $\mathrm{O} 157: \mathrm{H7}$, Salmonella 2.03, and for L. monocytogenes $0.71 \mathrm{log} \mathrm{cfu} / \mathrm{g}$. They concluded that $\mathrm{scCO}_{2}$ can be used for drying while offering a good inactivation of these pathogens, as well as most of the bacteria in the vegetative form naturally occurring on coriander. Michelino et al. [52] examined that supercritical carbon dioxide $\left(\mathrm{scCO}_{2}\right)$ drying in combination with high power ultrasound (HPU) to enhance the microbial inactivation on coriander leaves. Study results show that $\mathrm{scCO}_{2}$ drying can inactivate microorganisms especially yeast and molds. By the treatment, mesophilic bacteria reduced down to $4 \mathrm{Log}$; however, they remain always above the quantification limit. $\mathrm{HPU}+\mathrm{scCO}_{2}$ process significantly better for the inactivation of mesophilic bacterial spores. And it demonstrates that the potential to ensure a better inactivation of microorganisms compared to $\mathrm{scCO}_{2}$ treatment alone.

One of the drying methods is freeze-drying in which the water is removed from the material by sublimation. Freezedried products have minor changes in color, flavor, chemical composition, and texture; therefore, this method is considered the best dehydration technique. However, it does not or very slightly damages microorganisms [16]. Li et al. [89] studied the effects of four different drying methods on bacterial viability and storage stability of probiotic-enriched apple snacks. These methods are air drying, freeze-drying, freezedrying followed by microwave vacuum drying, and air drying followed by explosion puffing drying. They concluded that the most suitable method is freeze-drying followed by microwave vacuum drying. Probiotic bacteria remained above $10^{6} \mathrm{cfu} / \mathrm{g}$ for 120 days at $25^{\circ} \mathrm{C}$. Duan et al. [90] determined how long the microorganism survived in white cabbage by combining microwave and freeze-drying methods. Results showed that the microwave treatment showed like sterilization effect. They believe that these results may be due to thermal and biological effects on microorganisms. Also, freeze-drying method alone was not enough, contrarily, the microbial population increased, due to the long sublimation phase. Therefore, lyophilization is a preferred drying method for the storage of pure strains.

Gamma irradiation has long been used for the sterilization of dried vegetables. It is known that irradiation does not cause toxic hazards when it is not more than $10 \mathrm{kGY}$, also it is effective in killing pests, preventing sprouting, delaying maturity, and improving food qualities [91]. Park et al. [92] investigated that microbial inactivation effect/qualities by gamma-irradiated freeze-dried apples, pears, strawberries, pineapples, and grapes. These fruits were gammairradiated at $0,1,2,3,4,5,10,12$, and15 $\mathrm{kGy}$. At the end of the study, microorganisms were not detected in samples except for grapes apples, strawberries, pears, pineapples and grapes after in 1, 4, 4, 5, and $12 \mathrm{kGy}$ of gamma irradiation, respectively, and results showed that freeze-dried fruits can be sterilized with a dose of $5 \mathrm{kGy}$, except for grapes, which require a dose of $12 \mathrm{kGy}$. Kortei et al. [93], for the fresh and dried mushroom (Pleurotus ostreatus) decontamination, used the gamma radiation. Dried mushrooms were irradiated at doses of $0,0.5,1,1.5$ and $2 \mathrm{kGy}$. They analyzed samples for the B. cereus, S. aureus, Salmonella spp., yeasts, and mold counts, and results show that the Gamma radiation is effective for the inactivation of the Salmonella spp., coliforms and S. aureus. Also, researchers indicated that D10 values for Bacillus cereus on the dried mushrooms recorded $2.50 \mathrm{kGy}$ and $1.90 \mathrm{kGy}$ respectively.

Another method is cold plasma treatment. This method, which contains ultraviolet (UV) photons, positive and negative ions and free radicals, can inactivate microorganisms in food without a high temperature increase [94]. Lee et al. [95] investigated the inactivation of the microorganism on the fresh vegetables and dried fruits by the microwavepowered cold plasma treatment. Results showed that tested pathogens inactivated, and also when $\mathrm{pH}$ reduced enhanced inactivation. Hertwig et al. [96] determined the inactivation effect of the air-plasma method on the microbial flora of various vegetable powders. Study results show that these methods provided approximately 4.0 logarithmic reduction. Only crushed oregano samples reduce was lower than other samples. They reported this result may be due to the initial native microbial load.

Ozone treatment is generally used for the prevention of bacterial growth and fungal decay, also the destruction of pesticides and chemical residues and degradation of aflatoxin from agricultural products [34, 97, 98]. Zorlugenç et al. [34] determined the inactivation efficiency of gaseous ozone and ozonated water on microbial flora and aflatoxin $\mathrm{B} 1$ content of dried figs. The samples were exposed to13.8 $\mathrm{mg} \mathrm{L}^{-1}$ ozone gas and $1.7 \mathrm{mg} \mathrm{L}^{-1}$ ozonated water 
for $7.5,15$, and $30 \mathrm{~min}$ and they determined aerobic mesophilic bacteria, E. coli, coliform, yeast and mold counts. At the end of the study, mesophilic bacteria were not completely inactivated whereas $E$. coli, coliforms, and yeast were completely destroyed. Also ozone applications were sufficient for inactivation of all molds and degradation of aflatoxin B1. They remarked that gaseous ozone was more effective than ozonated water for the reduction of aflatoxin B1. Akbaş and Özdemir [99] in their study investigated the effect of ozonation on the inactivation of E. coli, B. cereus, and $B$. cereus spores in dried figs. Dried figs exposed to the ozone. At the end of the study, pathogen numbers reduced by approximately $3.5 \log$ at $1.0 \mathrm{ppm}$ ozone concentration. Also, researchers emitted that this method can be effective especially in the reduction of vegetative cells in dried figs. Although ozone is extremely soluble in water, among the causes of these results; there are several factors such as temperature, $\mathrm{pH}$, ozone bubble sizes, flow rate, and contact.

\section{Conclusion and future trend perspectives}

Dry foods are considered generally microbiologically clean and safe, by consumers. However, these foods can be contaminated with foodborne pathogens, and this contamination can lead to foodborne outbreaks. During the drying process and at the end, aw is adjusted to the level that microorganisms cannot survive. However, various reasons such as not being able to dehumidify enough during the process, inappropriate storage after the procedure, inappropriate packaging selection, and high initial microorganism load are the main causes of health risks.

To protect consumer health and at the same time eliminate/minimize these health risks, formulas such as combined drying methods or pretreatment are being developed. Among these pre-treatments, various solutions such as $\mathrm{NaCl}$, citric acid, ascorbic acid, sodium metabisulfite, sulfur, and blanching are preferred. Sulfur and sulfite compounds can cause asthmatic reactions in some people; however, especially sodium metabisulfite and acid treatments are effective in drying food. Also, ascorbic acid is one of these acids and the most preferred. It is generally considered as GRAS and helps to keep the color of dried fruits by preventing browning.

The use of combined technologies needs further investigation in terms of barrier effects. These technologies are; In addition to conditions such as drying time, temperature profile, pressure profile, pre-treatment, and initial number and type of target microorganism, it should first be evaluated individually for its effect on microbial inactivation. After this evaluation, its effectiveness should be compared with pasteurization/sterilization processes. In addition, some parameters are important for these developed methods to be effective. These include the microbiological load and quality of the raw material, processing and storage conditions, as well as the right packaging selection.

The drying methods developed in recent years and created by combining various combinations give good results both in terms of microorganism inactivation and preserving the nutritional quality of the food.

Especially for the surface decontamination of fruits such as fig, was found to be effective to the combination of Infrared heating with UV irradiation. Considering the results of the studies, sterilization by irradiation stands out as an effective method for inactivating microorganisms in dried fruits at a level close to $100 \%$. Also among these combined methods, low-pressure superheated steam drying (LPSSD) attracts a lot of attention. When evaluated on the basis of microorganisms, it is seen that LPSSD is one of the most effective methods to decrease Salmonella spp. The effect of this drying method is thought to be due to the steam temperature being over $100^{\circ} \mathrm{C}$.

Dried foods should not be considered immediately safe for pathogens, it is important for human health, to behave cautiously considering factors such as the method used in production, harvest quality of food. In addition to the effective implementation of procedures such as HACCP and good manufacturing practices, personnel hygiene and prevention of contamination are among the topics to be considered to ensure the safety of dried foods.

\section{Declarations}

Conflict of interest The authors declare no conflict of interest.

Ethical approval This article does not contain any studies with human participants or animals performed by any of the authors.

\section{References}

1. Vega-Mercado H, Góngora-Nieto MM, Barbosa-Cánovas GV (2001) Advances in dehydration of foods. J Food Eng 49(4):271289. https://doi.org/10.1016/S0260-8774(00)00224-7

2. Saldamlı İ, Saldamlı E (2004) In: Saldamlı İ (ed) Food industry machinery, 2nd edn. Savaş Publisher, Türkiye

3. Kutlu N, İșcí A, Demİrkol Öș (2015) Thin layer drying models in food systems. GIDA J Food 40(1):39-46

4. Sehrawat R, Nema PK, Kaur BP (2016) Effect of superheated steam drying on properties of foodstuffs and kinetic modeling. Innov Food Sci Emerg Technol 34:285-301. https://doi.org/10. 1016/j.ifset.2016.02.003

5. Zhang M, Chen H, Mujumdar AS, Tang J, Miao S, Wang Y (2017) Recent developments in high-quality drying of vegetables, fruits, and aquatic products. Crit Rev Food Sci Nutr 57(6):1239-1255. https://doi.org/10.1080/10408398.2014.979280

6. Eni AO, Oluwawemitan IA, Solomon OU (2010) Microbial quality of fruits and vegetables sold in Sango Ota Nigeria. Afr J Food Sci 4(5):291-296. https://doi.org/10.5897/AJFS.9000186 
7. Buyukunal S K, Issa G, Aksu F, Vural A (2015) Microbiological quality of fresh vegetables and fruits collected from supermarkets in Istanbul, Turkey. J Food Nutr Sci 3(4):152-159. https://doi.org/ 10.11648/j.jfns.20150304.13

8. Tango CN, Wei S, Khan I, Hussain MS, Kounkeu PFN, Park JH, Oh DH (2018) Microbiological quality and safety of fresh fruits and vegetables at retail levels in Korea. J Food Sci 83(2):386-392. https://doi.org/10.1111/1750-3841.13992

9. Hassan ZH, Purwani EY (2016) Microbiological aspect of fresh produces as retailed and consumed in West Java, Indonesia. Int Food Res J 23(1)

10. Heaton JC, Jones K (2008) Microbial contamination of fruit and vegetables and the behaviour of enteropathogens in the phyllosphere: a review. J Appl Microbiol 104(3):613-626. https://doi. org/10.1111/j.1365-2672.2007.03587.x

11. Qadri OS, Yousuf B, Srivastava AK (2015) Fresh-cut fruits and vegetables: critical factors influencing microbiology and novel approaches to prevent microbial risks-a review. Cogent Food Agric 1(1):1121606. https://doi.org/10.1080/23311932.2015. 1121606

12. Karam MC, Petit J, Zimmer D, Djantou EB, Scher J (2016) Effects of drying and grinding in production of fruit and vegetable powders: a review. J Food Eng 188:32-49. https://doi.org/10.1016/j. jfoodeng.2016.05.001

13. Ahmed J, Sinha N, Hui Y (2011) In: Sinha N (ed) Drying of vegetables: principles and dryer design. Handbook of vegetables and vegetable processing, 1st edn. Wiley-Blackwell, USA

14. Beuchat LR, Komitopoulou E, Beckers H, Betts RP, Bourdichon F, Fanning S, Ter Kuile BH (2013) Low-water activity foods: increased concern as vehicles of foodborne pathogens. J Food Prot 76(1):150-172. https://doi.org/10.4315/0362-028X.JFP-12-211

15. Barta J (2006) In: Sinha N (ed) Fruit drying principles. Handbook of fruits and fruit processing, 2nd edn. Wiley-Blackwell, USA

16. Zhang M (2017b) In: Mujumdar AS (ed) Microbiology and safety of dried vegetables, 2nd edn. Taylor \& Francis, New York

17. Cemeroğlu BS (2011) In: Cemeroğlu BS (ed) Fruit and vegetable processing technology, 2nd edn. Bizim Büro Publisher, Türkiye

18. Özler E, Ergüneş G, Tarhan S (2006) Mısırda Farkli Ön Işlemlerin Kuruma Hızına Etkisi. Anadolu Tarım Bilimleri Dergisi 21(2):160-166

19. Dipersio PA, Kendall PA, Calicioglu M, Sofos JN (2003) Inactivation of Salmonella during drying and storage of apple slices treated with acidic or sodium metabisulfite solutions. J Food Prot 66(12):2245-2251. https://doi.org/10.4315/0362-028X-66.12. 2245

20. Derrickson-Tharrington E, Kendall PA, Sofos JN (2005) Inactivation of Escherichia coli O157: H7 during storage or drying of apple slices pretreated with acidic solutions. Int J Food Microbiol 99(1):79-89. https://doi.org/10.1016/j.ijfoodmicro.2004.07.015

21. DiPersio PA, Kendall PA, Sofos JN (2004) Inactivation of Listeria monocytogenes during drying and storage of peach slices treated with acidic or sodium metabisulfite solutions. Food Microbiol 21(6):641-648. https://doi.org/10.1016/j.fm.2004.03.011

22. Yoon Y, Stopforth JD, Kendall PA, Sofos JN (2004) Inactivation of Salmonella during drying and storage of Roma tomatoes exposed to predrying treatments including peeling, blanching, and dipping in organic acid solutions. J Food Prot 67(7):1344-1352. https://doi.org/10.4315/0362-028X-67.7.1344

23. Pao S, Petracek PD (1997) Shelf life extension of peeled oranges by citric acid treatment. Food Microbiol 14(5):485-491. https:// doi.org/10.1006/fmic.1997.0109

24. Uyttendaele M, Neyts K, Vanderswalmen H, Notebaert E, Debevere J (2004) Control of Aeromonas on minimally processed vegetables by decontamination with lactic acid, chlorinated water, or thyme essential oil solution. Int J Food Microbiol 90(3):263-271. https://doi.org/10.1016/S0168-1605(03)00309-X
25. Yu K, Newman MC, Archbold DD, Hamilton-Kemp TR (2001) Survival of Escherichia coli O157: H7 on strawberry fruit and reduction of the pathogen population by chemical agents. J Food Prot 64(9):1334-1340. https://doi.org/10.4315/0362-028x-64.9. 1334

26. Chiewchan N, Morakotjinda P (2009) Effects of acetic acid pretreatment and hot air drying on resistance of Salmonella on cabbage slices. Drying Technol 27(9):955-961. https://doi.org/10. 1080/07373930902901992

27. Phungamngoen C, Chiewchan N, Devahastin S (2013) Effects of various pretreatments and drying methods on Salmonella resistance and physical properties of cabbage. J Food Eng 115(2):237244. https://doi.org/10.1016/j.jfoodeng.2012.10.020

28. Doymaz I, Pala M (2002) The effects of dipping pretreatments on air-drying rates of the seedless grapes. J Food Eng 52(4):413-417. https://doi.org/10.1016/S0260-8774(01)00133-9

29. Telis VR, Lourençon VA, Santos EM, Borin I, Gabas AL, TelisRomero J (2004) Drying rates of Rubi grapes as affected by nonconventional chemical pre-treatments, vol 100, Sao Paulo, Brazil, pp 1844-1850. http://dx.doi.org/10.1590/S0100-204X200600 0300018

30. Yokuş B (2014) Effects of different pre-treatments and different drying methods applied on total phenol amount and antioxidant activity in apples. Master's thesis, Bilecik Şeyh Edebali University

31. Duman İ, Şen F, Arda E (2010) Organic Dry Tomato Production, Storage and Processing. Hasad 301:94-102

32. Kidmose U, Martens HJ (1999) Changes in texture, microstructure and nutritional quality of carrot slices during blanching and freezing. J Sci Food Agric 79(12):1747-1753. https://doi.org/10. 1002/(SICI)1097-0010(199909)79:12<1747::AID-JSFA429>3 . $0 . \mathrm{CO} ; 2-\mathrm{B}$

33. Öztekin S, Zorlugenç B, Zorlugenç FK (2006) Effects of ozone treatment on microflora of dried figs. J Food Eng 75(3):396-399. https://doi.org/10.1016/j.jfoodeng.2005.04.024

34. Zorlugenç B, Zorlugenç FK, Öztekin S, Evliya IB (2008) The influence of gaseous ozone and ozonated water on microbial flora and degradation of aflatoxin B1 in dried figs. Food Chem Toxicol 46(12):3593-3597. https://doi.org/10.1016/j.fct.2008.09.003

35. Piyasena P, Mohareb E, McKellar RC (2003) Inactivation of microbes using ultrasound: a review. Int $\mathrm{J}$ Food Microbiol 87(3):207-216. https://doi.org/10.1016/S0168-1605(03)00075-8

36. Butz P, Tauscher B (2002) Emerging technologies: chemical aspects. Food Res Int 35(2-3):279-284. https://doi.org/10.1016/ S0963-9969(01)00197-1

37. Dolatowski ZJ, Stadnik J, Stasiak D (2007) Applications of ultrasound in food technology. Acta Sci Polonorum Technol Alimentaria 6(3):88-99

38. Butz P, Needs EC, Baron A, Bayer O, Geisel B, Gupta B, Tauscher B (2003) Consumer attitudes to high pressure food processing. J Food Agric Environ 1:30-34

39. Isman B, Biyik $H$ (2009) The aflatoxin contamination of fig fruits in Aydin City (Turkey). J Food Saf 29(2):318-330. https://doi.org/ 10.1111/j.1745-4565.2009.00159.x

40. Hamanaka D, Uchino T, Hu W, Yasunaga E (2002) Effects of infrared radiation on inactivation of Bacillus subtilis spore and Aspergillus niger spore. J Jpn Soc Agric Mach 64(6):69-75. https://doi.org/10.11357/jsam1937.64.6_69

41. Hamanaka D, Uchino T, Hu W, Yasunaga E, Sorour HM (2003) Effects of infrared radiation on the disinfection for wheat and soybean. J Jpn Soc Agric Mach 65(2):64-70. https://doi.org/10. 11357/jsam1937.65.2_64

42. Hamanaka D, Norimura N, Baba N, Mano K, Kakiuchi M, Tanaka F, Uchino T (2011) Surface decontamination of fig fruit by combination of infrared radiation heating with ultraviolet irradiation. Food Control 22(3-4):375-380. https://doi.org/10.1016/j.foodc ont.2010.09.005 
43. Farkas J (2006) Irradiation for better foods. Trends Food Sci Technol 17(4):148-152. https://doi.org/10.1016/j.tifs.2005.12.003

44. Afshari R, Hosseini H (2014) Non-thermal plasma as a new food preservation method, its present and future prospect. J Paramed Sci 5:2008-2078

45. Fernández A, Thompson A (2012) The inactivation of Salmonella by cold atmospheric plasma treatment. Food Res Int 45(2):678684. https://doi.org/10.1016/j.foodres.2011.04.009

46. Bonizzoni G, Vassallo E (2002) Plasma physics and technology; industrial applications. Vacuum 64(3-4):327-336. https://doi.org/ 10.1016/S0042-207X(01)00341-4

47. Cserhalmi Z, Sass-Kiss A, Tóth-Markus M, Lechner N (2006) Study of pulsed electric field treated citrus juices. Innov Food Sci Emerg Technol 7(1-2):49-54. https://doi.org/10.1016/j.ifset.2005. 07.001

48. Elez-Martínez P, Soliva-Fortuny RC, Martín-Belloso O (2006) Comparative study on shelf life of orange juice processed by high intensity pulsed electric fields or heat treatment. Eur Food Res Technol 222(3-4):321. https://doi.org/10.1007/ s00217-005-0073-3

49. Mosqueda-Melgar J, Elez-Martinez P, Raybaudi-Massilia RM, Martin-Belloso O (2008) Effects of pulsed electric fields on pathogenic microorganisms of major concern in fluid foods: a review. Crit Rev Food Sci Nutr 48(8):747-759. https://doi.org/10.1080/ 10408390701691000

50. Pan Y, Sun DW, Han Z (2017) Applications of electromagnetic fields for nonthermal inactivation of microorganisms in foods: an overview. Trends Food Sci Technol 64:13-22. https://doi.org/10. 1016/j.tifs.2017.02.014

51. Spilimbergo S, Komes D, Vojvodic A, Levaj B, Ferrentino G (2013) High pressure carbon dioxide pasteurization of fresh-cut carrot. J Supercrit Fluids 79:92-100. https://doi.org/10.1016/j. supflu.2012.12.002

52. Michelino F, Zambon A, Vizzotto T, Cozzi S, Spilimbergo S (2018) High power ultrasound combined with supercritical carbon dioxide for the drying and microbial inactivation of coriander. $\mathrm{J}$ CO2 Util 24:516-521. https://doi.org/10.1016/j.jcou.2018.02.010

53. Phungamngoen C, Chiewchan N, Devahastin S (2011) Thermal resistance of Salmonella enterica serovar Anatum on cabbage surfaces during drying: effects of drying methods and conditions. Int J Food Microbiol 147(2):127-133. https://doi.org/10.1016/j.ijfoo dmicro.2011.03.019

54. Smelt JPPM, Brul S (2014) Thermal inactivation of microorganisms. Crit Rev Food Sci Nutr 54(10):1371-1385. https://doi.org/ 10.1080/10408398.2011.637645

55. Abee T, Wouters JA (1999) Microbial stress response in minimal processing. Int J Food Microbiol 50(1-2):65-91

56. Guchte MVD, Serror MP, Chervaux C, Smokvina T, Ehrlich SD, Maguin E (2002) Stress responses in lactic acid bacteria. Antonie Van Leeuwenhoek 82:187-216. https://doi.org/10.1023/A:10206 31532202

57. Ghandi A, Powell IB, Broome M, Adhikari B (2013) Survival, fermentation activity and storage stability of spray dried Lactococcus lactis produced via different atomization regimes. J Food Eng 115(1):83-90. https://doi.org/10.1016/j.jfoodeng.2012.09.022

58. Chitrakar B, Zhang M, Adhikari B (2019) Dehydrated foods: are they microbiologically safe? Crit Rev Food Sci Nutr 59(17):27342745. https://doi.org/10.1080/10408398.2018.1466265

59. Morgan CA, Herman N, White PA, Vesey G (2006) Preservation of micro-organisms by drying; a review. J Microbiol Methods 66(2):183-193. https://doi.org/10.1016/j.mimet.2006.02.017

60. Higl B, Kurtmann L, Carlsen CU, Ratjen J, Först P, Skibsted LH, Risbo J (2007) Impact of water activity, temperature, and physical state on the storage stability of Lactobacillus paracasei ssp. paracasei freeze-dried in a lactose matrix. Biotechnol Prog 23(4):794-800. https://doi.org/10.1021/bp070089d
61. Finn S, Condell O, McClure P, Amézquita A, Fanning S (2013) Mechanisms of survival, responses and sources of Salmonella in low-moisture environments. Front Microbiol 4:331. https:// doi.org/10.3389/fmicb.2013.00331

62. Hawaree N, Chiewchan N, Devahastin S (2009) Effects of drying temperature and surface characteristics of vegetable on the survival of Salmonella. J Food Sci 74(1):E16-E22. https://doi. org/10.1111/j.1750-3841.2008.01010.x

63. Singh S, Singh SK, Chowdhury I, Singh R (2017) Understanding the mechanism of bacterial biofilms resistance to antimicrobial agents. Open Microbiol J 11:53. https://doi.org/10.2174/ 1874285801711010053

64. Archer J, Jervis ET, Bird JON, Gaze JE (1998) Heat resistance of Salmonella weltevreden in low-moisture environments. J Food Prot 61(8):969-973. https://doi.org/10.4315/0362-028X61.8.969

65. Patel R (2005) Biofilms and antimicrobial resistance. Clin Orthop Relat Res 437:41-47. https://doi.org/10.1097/01.blo.0000175714. 68624.74

66. Kieboom J, Kusumaningrum HD, Tempelaars MH, Hazeleger WC, Abee T, Beumer RR (2006) Survival, elongation, and elevated tolerance of Salmonella enterica serovar Enteritidis at reduced water activity. J Food Prot 69(11):2681-2686. https:// doi.org/10.4315/0362-028X-69.11.2681

67. Stackhouse RR, Faith NG, Kaspar CW, Czuprynski CJ, Wong ACL (2012) Survival and virulence of Salmonella enterica serovar enteritidis filaments induced by reduced water activity. Appl Environ Microbiol 78(7):2213-2220. https://doi.org/10.1128/ AEM.06774-11

68. Bourdoux S, Li D, Rajkovic A, Devlieghere F, Uyttendaele M (2016) Performance of drying technologies to ensure microbial safety of dried fruits and vegetables. Compr Rev Food Sci Food Saf 15(6):1056-1066. https://doi.org/10.1111/1541-4337.12224

69. Burnham JA, Kendall PA, Sofos JN (2001) Ascorbic acid enhances destruction of Escherichia coli O157: H7 during hometype drying of apple slices. J Food Prot 64(8):1244-1248. https:// doi.org/10.4315/0362-028X-64.8.1244

70. Bang J, Kim H, Kim H, Beuchat LR, Ryu JH (2011) Combined effects of chlorine dioxide, drying, and dry heat treatments in inactivating microorganisms on radish seeds. Food Microbiol 28:114-118. https://doi.org/10.1016/j.fm.2010.09.002

71. DiPersio PA, Kendall PA, Yoon Y, Sofos JN (2007) Influence of modified blanching treatments on inactivation of Salmonella during drying and storage of carrot slices. Food Microbiol 24(5):500 507. https://doi.org/10.1016/j.fm.2006.09.004

72. Belessiotis V, Delyannis E (2011) Solar drying. Sol Energy 85(8):1665-1691. https://doi.org/10.1016/j.solener.2009.10.001

73. Kudjawu BD, Sakyi-Dawson E, Amoa-Awua WK (2011) The microbiota of dried traditional vegetables produced in the Sudan Savannah and Guinea Savannah agro-ecological zones of Ghana. Int Food Res J 18(1):101-107

74. Bai X, Campagnoli M, Butot S, Putallaz T, Michot L, Zuber S (2020) Inactivation by osmotic dehydration and air drying of Salmonella, Shiga toxin-producing Escherichia coli, Listeria monocytogenes, hepatitis A virus and selected surrogates on blueberries. Int J Food Microbiol 320:108522. https://doi.org/10.1016/j. ijfoodmicro.2020.108522

75. Zhang M, Tang J, Mujumdar AS, Wang S (2006) Trends in microwave-related drying of fruits and vegetables. Trends Food Sci Technol 17(10):524-534. https://doi.org/10.1016/j.tifs.2006.04. 011

76. Yaghmaee P, Durance T (2007) Efficacy of vacuum microwave drying in microbial decontamination of dried vegetables. Drying Technol 25(6):1099-1104. https://doi.org/10.1080/0737393070 1397301 
77. Jiang H, Zhang M, Mujumdar AS (2010) Physico-chemical changes during different stages of MFD/FD banana chips. J Food Eng 101(2):140-145. https://doi.org/10.1016/j.jfoodeng.2010.06. 002

78. Woo IS, Rhee IK, Park HD (2000) Differential damage in bacterial cells by microwave radiation on the basis of cell wall structure. Appl Environ Microbiol 66(5):2243-2247. https://doi.org/10. 1128/AEM.66.5.2243-2247.2000

79. Daglioglu O, Arici M, Konyali M, Gumus T (2002) Effects of tarhana fermentation and drying methods on the fate of Escherichia coli O157: $\mathrm{H} 7$ and Staphylococcus aureus. Eur Food Res Technol 215(6):515-519. https://doi.org/10.1007/ s00217-002-0584-0

80. Guirguis EAH (2018) Assessment of the microbiological and mycotoxins quality of selected dried fruits with special reference to microwave treatment. IOSR J Environ Sci Toxicol Food Technol 12(10):48-55. https://doi.org/10.9790/2402-1210014855

81. Kozempel MF, Annous BA, Cook RD, Scullen OJ, Whiting RC (1998) Inactivation of microorganisms with microwaves at reduced temperaturas. J Food Prot 61(5):582-585. https://doi.org/ 10.4315/0362-028X-61.5.582

82. Jun S, Irudayaraj J (2003) A dynamic fungal inactivation approach using selective infrared heating. Trans ASAE 46(5):1407. https:// doi.org/10.13031/2013.15435

83. Sakai N, Mao N (2006) In: Sun D (ed) Infrared heating, in thermal food processing, 3rd edn. Taylor \& Francis, Florida

84. Krishnamurthy K, Khurana HK, Soojin J, Irudayaraj J, Demirci A (2008) Infrared heating in food processing: an overview. Compr Rev Food Sci Food Saf 7(1):2-13. https://doi.org/10.1111/j.15414337.2007.00024.x

85. Gabel MM, Pan Z, Amaratunga KSP, Harris LJ, Thompson JF (2006) Catalytic infrared dehydration of onions. J Food Sci 71(9):E351-E357. https://doi.org/10.1111/j.1750-3841.2006. 00170.x

86. Spilimbergo S, Elvassore N, Bertucco A (2002) Microbial inactivation by high-pressure. J Supercrit Fluids 22(1):55-63. https:// doi.org/10.1016/S0896-8446(01)00106-1

87. Calvo L, Torres E (2010) Microbial inactivation of paprika using high-pressure CO2. J Supercrit Fluids 52(1):134-141. https://doi. org/10.1016/j.supflu.2009.11.002

88. Zambon A, Michelino F, Bourdoux S, Devlieghere F, Sut S, Dallacqua S, Spilimbergo S (2018) Microbial inactivation efficiency of supercritical CO2 drying process. Drying Technol 36(16):20162021. https://doi.org/10.1080/07373937.2018.1433683

89. Li C, Li-ying N, Da-jing L, Chun-quan L, Ying-ping L, Chun-ju L, Jiang-feng S (2018) Effects of different drying methods on quality, bacterial viability and storage stability of probiotic enriched apple snacks. J Integr Agric 17(1):247-255. https://doi.org/10. $1016 /$ S2095-3119(17)61742-8
90. Duan X, Zhang M, Mujumdar AS (2007) Studies on the microwave freeze drying technique and sterilization characteristics of cabbage. Drying Technol 25(10):1725-1731. https://doi.org/10. 1080/07373930701591044

91. Wang J, Chao Y (2002) Drying characteristics of irradiated apple slices. J Food Eng 52(1):83-88. https://doi.org/10.1016/S02608774(01)00090-5

92. Park JN, Sung NY, Byun EH, Byun EB, Song BS, Kim JH, Lyu ES (2015) Microbial analysis and survey test of gamma-irradiated freeze-dried fruits for patient's food. Radiat Phys Chem 111:5761. https://doi.org/10.1016/j.radphyschem.2015.02.011

93. Kortei NK, Odamtten GT, Appiah V, Obodai M, Adu-Gyamfi A, Annan T, Mills SWO (2014) Microbiological quality assessment of gamma irradiated fresh and dried mushrooms (Pleurotus ostreatus) and determination of D10 values of Bacillus cereus in storage packs. https://csirspace.foodresearchgh.site/handle/12345 6789/339

94. Fernández A, Shearer N, Wilson DR, Thompson A (2012) Effect of microbial loading on the efficiency of cold atmospheric gas plasma inactivation of Salmonella enterica serovar Typhimurium. Int J Food Microbiol 152(3):175-180. https://doi.org/10.1016/j. ijfoodmicro.2011.02.038

95. Lee H, Kim JE, Chung MS, Min SC (2015) Cold plasma treatment for the microbiological safety of cabbage, lettuce, and dried figs. Food Microbiol 51:74-80. https://doi.org/10.1016/j.fm.2015.05. 004

96. Hertwig C, Reineke K, Ehlbeck J, Erdoğdu B, Rauh C, Schlüter $\mathrm{O}$ (2015) Impact of remote plasma treatment on natural microbial load and quality parameters of selected herbs and spices. J Food Eng 167:12-17. https://doi.org/10.1016/j.jfoodeng.2014.12.017

97. Kells SA, Mason LJ, Maier DE, Woloshuk CP (2001) Efficacy and fumigation characteristics of ozone in stored maize. J Stored Prod Res 37:371-382. https://doi.org/10.1016/S0022-474X(00) 00040-0

98. Sharma RR, Demirci A, Beuchat LR, Fett WF (2002) In activation of Escherichia coli O157:H7 on inoculated alfalfa seeds with ozonated water and heat treatment. J Food Prot 65:447-451

99. Akbas MY, Ozdemir M (2008) Application of gaseous ozone to control populations of Escherichia coli, Bacillus cereus and Bacillus cereus spores in dried figs. Food Microbiol 25(2):386-391. https://doi.org/10.1016/j.fm.2007.09.007

Publisher's Note Springer Nature remains neutral with regard to jurisdictional claims in published maps and institutional affiliations. 